\title{
The Public Policy in Agricultural Product Markets and Effectiveness of Regulations
}

\author{
Prof. Dr. Mehmet Okan Taşar (Selçuk University, Turkey)
}

\begin{abstract}
Parallel to the developments in the global economy, perhaps the most problematic market structure within the liberalization process in the transition economies and in the Turkish economy is highlighted as agricultural product markets. The effects of agricultural product prices on other macroeconomic indicators and the fundamental economic problems such as inflation, income distribution, poverty and unemployment constitute a fundamental dynamic. At this point, public policies and regulations of market processes need to be analyzed in terms of the effects they will cause.

The purpose of this paper is to analyze the effects of interventions and regulations on agricultural products markets on market economy and macroeconomic indicators. However, it will be possible to establish the most appropriate agricultural policies possible for the macroeconomic performance of the Turkish economy. In the first section; the impacts and consequences of regulations will be determined by establishing the relationship between agricultural product markets and government interventions. The second part is to analyze these effects and results with the help of data and indicators belonging to the Turkish economy and to analyze the different effects caused by the applied agricultural regulations. The last part is; the discussion of rational agricultural intervention policies and regulations with the least possible negative impact.
\end{abstract}

\section{Introduction}

Due to the importance of agricultural products in terms of humanity, the intervention and regulation of the states in these periods attracts attention in all periods of human history. One of the most important features distinguishing agricultural markets from other markets is; High potential to be affected by climate, geography and political developments, the foundation of disasters such as famine, famine and drought, and an unstable market operation structure. The production and trade of agricultural products determines the periods of human history and technical development or differences constitute the main dynamic of social transformations. In the theory of economics, agricultural markets also constitute the focal point of important debates.

When we look at the state interventions for agricultural product markets and their historical practices in terms of regulations, agricultural policies are used in tribal states, Ancient Greek city states and central empires, as well as global empires such as Rome and the Ottoman Empire. The strategic importance of agricultural products and agricultural production techniques such as "latifundia" or "timar system" in each period is defined as a factor that can change the course of history. The fact that the agricultural sector is adequate and developed, especially in economic terms, is becoming the most important macroeconomic factor determining the prosperity and stability of societies.

After the Industrial Revolution, the second plat- form due to the industrialization-oriented growth structure of the agricultural sector and its socio-economic orientation towards the industrial cities of the rural population reveals significant structural problems in all economies. In addition, the application of technological developments to the agricultural sector is possible in a slower and more limited framework than in other sectors. In addition, free foreign trade and liberalization policies are present in all sectors as well as some side effects in agricultural production areas. Although free market economies in general can be said to have positive effects in industrial sectors, it is known that they lead to a series of "market failures" in terms of agricultural markets. The "invisible hand" which is theoretically the most basic automatic balancer in all the markets of the economy is not working because the supply-demand balance depends on the different period prices of these functions in agricultural product markets. Therefore, agricultural product markets are attracting attention due to unstable price and production structure. This instability is; Agricultural products are leading to serious consequences due to the importance of human life, economic development and effects on social prosperity.

Structural instability in agricultural product markets affects not only agricultural products but also production in all sectors of the economy, determining price movements and causing significant macroeconomic distortions such as poverty and income distribution imbalances. On the other hand, it disturbs the demographic structure of the population and aggravates the problems of urbanization and unemployment. The impoverishment of the rural population is also a determinant of a general poverty and income distribution inequality that can affect an entire society. For this reason today; It is considered an absolute necessity to include agricultural planning and agricultural policy in all economic systems, either developed or underdeveloped. Agriculture and rural development, beyond being a problem that can only be solved by national policies, require an international level of cooperation and policy. Successful and coordinated agricultural policy and cooperation is linked to; Poverty, injustice, social conflict and chaos as well as macroeconomic problems such as unemployment, inflation and economic contraction. 
While discussing the boundaries of the state's intervention in the economy and the dimensions of this intervention in the current economic literature, the policy tools used by the state of intervention in the agricultural product markets are questioned, not the existence of state intervention. Therefore, state intervention in agricultural markets is accepted in all economic systems, but there are disagreements over the economic consequences and side effects of the methods used. At this point, it is of great importance to determine the right agriculture and pricing policies to be implemented in order to realize social development and economic development goals without disturbing the market operation structures.

Parallel to the developments in the global economy, perhaps the most problematic market structure within the liberalization process in the transition economies and in the Turkish economy is highlighted as agricultural product markets. The effects of agricultural product prices on other macroeconomic indicators and the fundamental economic problems such as inflation, income distribution, poverty and unemployment constitute a fundamental dynamic. At this point, state intervention and regulation of market processes need to be analyzed in terms of the effects they will cause. The purpose of this study is to analyze the effects of interventions and regulations on agricultural products markets on market economy and macroeconomic indicators. However, it will be possible to establish the most appropriate agricultural policies possible for the macroeconomic performance of the Turkish economy. In the first section; the impacts and consequences of regulations will be determined by establishing the relationship between agricultural product markets and government interventions. The second part is to analyze these effects and results with the help of data and indicators belonging to the Turkish economy and to analyze the different effects caused by the applied agricultural regulations. The last part is; the discussion of rational agricultural intervention policies and regulations with the least possible negative impact.

\section{Global Tendencies on Agricultural Policies}

Agricultural policy refers to the whole of state interventions designed to influence the socio-economic and technical environment of agricultural activity. This definition reveals that each policy is shaped around a specific objective function and that it is equipped with the necessary tools to achieve the goals set out. Today, policies on the agricultural sector, which have become part of the general economy, constitute a sub-component of macroeconomic policies subject to cross-sectoral interactions (Şahinöz, 2010).

Neo-Classical Economy has adopted to some extent the state intervention in the early 1960s, with the experience of development planning in the poor countries, the first steps towards development, and the elimination of market failures. However, with the approach that state intervention is necessary in the coming period, the gradual weakening of the concept of developmental state points to a clear contradiction. The Washington Consensus and the Post Washington Consensus continue to understand that the role of the state in growing up in poor countries is rather limited (Byres, 2009). In agriculture, however, there are certain basic and important functions that only the state can bear. This role of the state; It also includes the application of protectionist foreign trade policies and import-duplication industrialization strategies in order to realize the structural transformation that has a critical role in important and historical examples of capitalist development. The same is true for land reform, co-operation, and other mechanisms instead of flexible "agricultural institutions". More importantly; requires an intense official credit and incentive program that does not involve excessive interest. There is a need for significant government interventions in the creation of modern irrigation facilities, in the dissemination of new technologies, in the control of inter-sectoral prices, and in rural poverty alleviation programs in particular. Without such an interventionist state, it is not possible to achieve a dynamic agricultural transformation in economically backward countries and to create a well-balanced agricultural commodity market (Byres, 2009).

\subsection{Agricultural Policy with UN and IMF Approach}

The main principle in rural development programs of recent period of United Nations becomes remarkable as a multi-sectorial development approach. This approach, based on the interaction of rural development between agricultural sector and the other sectors, is expressed as the main components of rural development (water, energy, health, agriculture, and bio-diversity/WEHAB) formed by World Sustainable Development Summit (Giray, et al, 2004).

Especially, in the recent period, the concept of "multifunctional agriculture" is similarly based on simultaneous development of the food goods, production, and service sectors in agricultural activities. Multifunctional agricultural approach, in both global scale and EU scale, has begun to be used in 1993 together with EU agricultural law and was also adopted by OECD (Marsden and Sonnino, 2008).

The new content of rural development was enlarged by considering the different economic activities. The different economic activities foresee differentiated economic activities in rural areas such as high-quality production and regional qualified products, environmental protection and land management, shortening supply chain, and development of rural tourism (Knickel and Renting, 2000). This approach overlaps with the concept of multifunctional agriculture concept. In addition, this approach, also considered in either United Nations and IMF or EU scale applications of agricultural and rural development policies, is accepted as a policy suggestion. 
Over the years there have been a number of strategies followed in order to invoke economic, political and social structural changes to rural areas. However, it is a field characterized as offering many fads and few satisfying economic evaluations. This is partly a reflection of the lack of a clear, common definition for what 'rural development' precisely means more than a decade after this was first prominently highlighted. The dominant approach during the majority of the last half century or more has been based on agricultural development. Indeed, rural development has been regarded as synonymous with agricultural development for much of its history. Even today, rural development is sometimes practiced with a single emphasis on agricultural development, and on productivity and modernization in particular. This has endured, partly because we generally know far more about the promotion of agricultural growth in rural areas than about the promotion of non-agricultural activities, but also because responsibility for rural development typically falls to government departments associated with agriculture in many countries.

\subsection{E.U. Common Agricultural Policy and Rural Development Approach}

Considering the US and EU countries, which are considered to be the two most important actors of world agricultural production, it is seen that they apply large scale protective agricultural policies especially for the agricultural products market. These countries, which have carried large amounts of income to agricultural producers, can easily be expressed in terms of their production quantity and diversity, and they constitute a significant part of agricultural production on a global scale and have a decisive position in agricultural markets (Acar, 2003).

The most important institutional structure that determines agricultural support policies in the United States is realized by the Product Credit Company (CCC), which was established in 1933 and has been operating since 1948 as a federal federation of the Ministry of Agriculture. This Authority; It has a wide range of activities such as supporting the prices of agricultural products through loans, purchases, payments and other activities, developing different alternatives for production and marketing, evaluating agricultural products on the domestic market, providing food assistance when necessary and finding foreign markets for more agricultural products. The EU Common Agricultural Policy, which is basically defined as a supportive and protective agricultural policy, is regarded as the most comprehensive, most protective support policy on a global scale (Acar, 2003).

Rural development policy is one of the main components of European Union Common Agricultural Policy beginning from the year 2000.EU Common Agricultural Policy attracts attention is one of the oldest programs of Union applied since 1962. In the first years, while a study was determined toward eliminating the problem with food insufficiency experienced after war, in the progressing periods; it is concentrated on planning production in agricultural products and increasing competitive power of European Agriculture (EU, 2014).

European Union (EU), in order to support the candidate and potential candidate countries, in the framework of Council Regulation, numbered 1085/2006, formed Instrument for Pre-Accession Assistance-IPA. Pre-Accession Assistance-IPA foresees aid to Turkey, Macedonia, Croatia, which are in candidate status in EU accession process and to the potential candidates. The main aim of IPA, in order to strengthen these countries, which are in the accession process, in the areas of institutional capacity, border cooperation, economic and social development, and rural development, is to make aid in a single framework. Pre-Accession Assistance-IPA, also considering the respective internal dynamics and country features of EU- candidate or potential candidate countries, supports the infrastructures of countries about their being stable and toward EU-membership. IPA, in order to provide a consistent and effective structuring, also considering the needs and priorities of countries, consists of five components as institutional structuring and supporting the pass from EU-candidate to full membership, crossborder cooperation, regional development, development of human resources, and rural development (Turhan, 2015).

Rural IPARD (Instrument for Pre-Accession Assistance-Rural Development: IPARD) supports adaptation preparations and development of policy in this scope for application and management of Common Agricultural Policy, Rural Development Policy, and the relevant policies of European Union. IPARD, which is fifth component of IPA, have two main aims. The first main aim of IPARD approach is to help the application of EU legislation relevant to Common Agricultural Policies and, in this framework, to support to the adoption of EU standards on the issues such as animal health, vegetable health, and food security. While the second aim is expressed in the form of providing support the sustainable development of agricultural sector and rural areas, in order to be able to reach these aims, there are three axes (Turhan, 2015).

$1^{\text {st }}$ Axis: Strengthening market efficiency and applying EU standards

$2^{\text {nd }}$ Axis: For Agriculture- Environment action to be applied, preparations of the necessary actions and infrastructure

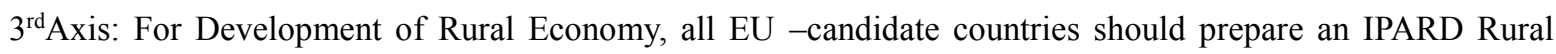
Development Program and, with an institutional structure (IPARD agency in the sample of Turkey), provided its accreditation process, and have to apply this program

For Turkey, IPA-Rural Development Program (IPARD Program), was designed by considering the priorities and needs in the pre-accession period of the country in the context of rural development. The main aim of Rural 
Development Program, approved by European Commission on the date of February 25, 2008, is to make contribution to the application of legal acquit related to EU Common Agricultural Policy, reaching some priorities for the adaptation of agricultural sector and rural areas in the candidate country, and solution of problems (Turhan, 2015). The following four sub-actions, adopted toward the aim of contributing to especially eliminate rural development unbalances attract attention.

* diversifying and developing the farm activities

*developing local products and micro businesses

* developing rural tourism, and

* developing culture fishing.

Together with rural development policy, EU Common Agricultural Policy shows structural features founded on two pillars. While the first pillar consists of direct payments made to agricultural sector, market regulations, and export supports, the second pillar includes policies in the area of rural development. $92 \%$ of EU surface area is defined as rural area; $53 \%$ of employment from the rural area; and $45 \%$ of added value is created in the rural areas. Therefore, the weight of rural agricultural policies in EU Common Policy gradually increases (Kulaklıkaya, 2015).

European Union Rural Development policy is fixed on the three main principles. Firstly, in the rural areas, via increasing the physical capacity of human resources and quality of agricultural products, policies toward competitive power is expressed. The second principle includes the bases related to the sustainable use of agricultural lands, protection of environment, and climatic adoption of change. The third principle is raising quality of life and adopting a multi-sectorial rural development approach, diversifying economic activities.

\section{The Qualities and Efficiency of Agricultural Policies and Regulations in Turkey}

\subsection{Historical Background of Agricultural Policies in Turkey}

First of all, agricultural policies are made up of that; basic price applications, agricultural support loans, tax exemptions and exemptions, technology information transfer, rural infrastructure projects. The base price and subsidy purchase policy for agricultural products in Turkey is starting from the 1930s. The historical process of the agricultural lending policy extends back to much earlier periods. The ongoing agricultural credit policy in Turkey is nourished from two different sources, namely organized and unorganized credit markets. The organized credit market is composed of banks, Agricultural Credit Cooperatives and Agricultural Sales cooperatives. However, as low interest agricultural credits are extended on the basis of the size of the enterprise and the size of the collateral shown, it may cause a side effect that disturbs distribution of favorable income for large farmers as it is for the implementation of the base price (Şahin, 1998)

The main approach in agriculture policy in these years has been to increase production, to promote all small and large private agricultural production units, because production in the first years of the Republic is a problem. In 1925 , the conversion of the monetary tax scheme by removing the same amount of tax taken in the agricultural sector increased the level of marketable production by creating an environment that encourages production in agriculture. Between 1923 and 1938, 3.7 million lands were distributed to a group of landless farmers and immigrants by the state. The agriculture sector has been developing rapidly with the opening of the state-handled lands and meralars. By 1929, a growth of 27\% was achieved in agriculture (Eştürk and Eren, 2014). These developments are developments that can be regarded as positive in terms of food safety. On the one hand, the food supply of the people has been improved, while on the other hand the increase in farmer incomes has increased the accessibility of food. During the period 1923-1931 grain and cereal stock exchanges were established and the stock exchanges were able to remove the price differences in the regions where they were located to a great extent, enabling the buyer and seller to operate safely and to systematically determine the quality and value of the products. In this period, Agricultural Credit and Agricultural Sales Cooperatives were established as the first and most important step of the farmers' organization and these organizations expanded their market opportunities by financing provided by Ziraat Bank and by purchasing the product which gave various inputs and credit support to its partners (Eştürk and Eren, 2014).

The period of 1938-1946 after the 1929 crisis is characterized as a period in which the intervention and solid stateism are dominant in terms of agricultural policies in Turkey. In the Second World War, as Turkey's relationship with the world states has been extremely weak, the country has had to supply an army far above its capabilities because of a possible war. Due to the duration of the war, the end of the mobilization, the keeping of the workforce under arms, the empty fields and the presence of adverse climatic conditions, serious shortages and scarcities were experienced in the supply of food products during this period. Wheat production, which has a significant share in agricultural production, declined during this period. The wheat production, which was 4,200 thousand tons in 1939, decreased to 2,200 thousand tons in 1945 (Eştürk and Eren, 2014). While the decline in agricultural production due to the conjuncture of war, especially in large cities, caused many food products to be subject to black market, bread was attached to carnation due to the flour shortage. The application of carding has been started, and it is forbidden to make flour pasta such as flour confectionery. Because of this, the government has made a 
more radical attempt to implement the "Milli Koruma Kanunu", which is one of the important developments of the period, since the regulations against the government preventing the stagnation related to the price determination of agricultural products have been weakened. By law, the government has gained the right to intervene widely in agriculture and commercial life; through the decree, the villagers and small farmers have the right to confiscate the assets of the foreign trade merchant and the workshop, factory and facilities of the industrialist. Although this is a practice created by war, it is often considered arbitrary. Particularly the peasant sector was very badly affected by the law. For the country, this period was the period when food insecurity in Republican history was felt the most in food poverty (Eştürk and Eren, 2014).

The aim of self-sufficiency, which struck the mark of agricultural policy in 1923-1950 periods, aimed to produce more and exports to foreign markets in the 1950s through mechanization. In this period, especially since 1948, the agriculture has been financed with the aid obtained under the Marshall Grant Scheme. With agricultural development, Marshall Aid became the driving force; The increase in the number of plows in agriculture, the increase in agricultural land lending, the increase in agricultural loans, support prices, good climatic conditions and the spread of fertilizer usage have increased production (Eştürk and Eren, 2014).

In the 1950s, as world prices fell below the prices in the country, incentive applications started in exports. In this period when price increases were accelerating, prices of agricultural products such as animal products, rice, bread and oil were intervened in order to protect the consumer. In terms of food safety, it can be said that this period is better than the years of famine during the Second World War, depending on the increases in agricultural production and productivity (Eştürk and Eren, 2014).

In the determination of agricultural policies, the planning period has been started since 1963 and depending on the basic principles of development plans; the government has been supporting and intervening in the agriculture sector in the first years, while the price support policy became the foreground in the following plan periods. From 1960 to 1980, with the import substitution method, agricultural production and productivity increase became the first aim of agriculture policies as a necessity of industrialization policies. The neo-liberal policies that were effective in the world from the 1980s to the present day became effective in determining the agriculture policies of our country. These are external dynamics such as IMF, WB, WTO and EU as actors. Those who act on these external dynamics are mostly economic crises living in the country. In the world, affected by the oil crises of the 1970s, Turkey has applied to the IMF for rid of the crisis and the need for external debt, and has agreed to implement the IMF's stabilization measures. These measures took place in the Decisions of 24 January 1980 and in subsequent implementations. The stabilization measures introduced in order to bring the market mechanism into operation have provided a minimum level of support to the public sector. Within the scope of these measures; Fertilizer prices were first raised and government support provided to other agricultural entrances was gradually lifted, and the prices of largely outsourced modern entrances were left to fluctuate according to the free exchange rate. The conditions of use of agricultural loans have been aggravated. While the agricultural subsidy prices have been reduced, the coverage of the number of supported products has been reduced to half (Eştürk and Eren, 2014).

The number of supported products reduced in the 1980s has been increased since the beginning of the 1990s, subsidy prices have been improved, agricultural loans have been increased and some of the accumulated debts of the farmers have been erased and the premium system on product basis started to be implemented in 1993. The increase in subsidies in agricultural products ensures the stability of the supply of agricultural products. This means regular and continuous availability of food for consumers, and income and price stability for producers. Süt Endüstrisi Kurumu (SEK), Et ve Balık Kurumu (EBK), "Türk Zirai Donatım Kurumu (Turkish Agricultural Equipment Corporation)" (TZDK), which have taken important roles in the development of agriculture and directed the agriculture sector in this period, with some measures taken in favor of agriculture in 1990s. These institutions were later privatized. With the withdrawal of these institutions, which constitute a market security for livestock and milk producers, there has been price instability in the market; Meat and dairy products. Another characteristic of these years is the Agriculture Agreement signed under the WTO, which entered into force in 1995, and the EU and Customs Union Agreements, which entered into force on 1 January 1996. In the direction of the Agriculture Agreement with the WTO, subsidy policies such as input subsidy and price support for agriculture have been reduced, and customs taxes, which protect agricultural products and producers from price fluctuations in international markets and encourage domestic production, have been reduced (Eştürk and Eren, 2014).

Since 2001, Turkey has changed all the support and incentive system applied in the agricultural area and switched to Direct Income Support (DIS). The agrarian policy implemented with the support of the World Bank has been shaped by three main elements of reform. The first element is; Secondly, the gradual abolition of price and input support, and the last element is the privatization of state enterprises in the hunting sector and the reduction of government intervention in the processing and marketing of agricultural products. In the application of DIS, the upper limit of supply for 2001 was determined to be 200 decares, and a payment of 10 TL per decare was adopted. Since 2002, the upper limit has been raised to 500 decares and the payment amount has been increased to $13.5 \mathrm{TL}$. Within the total support payments, the share allocated for DIS was $14 \%$ while it reached $83 \%$ in 2002. Since 2002, the share of DIS share has gradually decreased and decreased to $19 \%$ for the year 2008 when the payments were concluded (Tan, et al, 2010). One of the basic principles of the DIS policy, which is accepted as one of the most 
important components of the Agricultural Reform Implementation Project (Tarım Reformu Uygulama Projesi TRUP), is the Farmer Registration System (Çiftçi Kayıt Sistemi-ÇKS). The main objective of the ÇKS is; it is the creation of a strong trial base by the manufacturers' registration (Tan, et al, 2010).

With the Agriculture Law published in the "Resmi Gazete" dated 25.04.2006 and numbered 26149, it is aimed to develop the agricultural production in a suitable way for the internal and external students and to preserve and develop natural and biological resources. It is also aimed to increase the level of prosperity in agriculture sector by increasing productivity, strengthening food safety and security, developing producer organizations, strengthening agricultural markets, and providing rural development. The main objective of agricultural subsidies is to contribute to the solution of the priority problems of the agriculture sector, to increase the effectiveness of applied policies and to make the sector easier to harmonize with this policy. In its opinion, agricultural subsidies policies will be implemented with programs that provide economic and social efficiency and productivity conditions. The means of agricultural support stated in the Law are; DIS, differential payment, compensatory payments, animal husbandry support, agricultural insurance payments, rural development support, environmental protection support (Yalçınkaya, et al, 2006).

\subsection{Effectiveness of Regulation and Public Policy}

In terms of Turkey agricultural policies of 2000s was formed in the framework of application project of agricultural reform, especially made International Monetary Fund and World Bank and EU Common Agricultural Policy in 20001 (Günaydın, 2009). In the content of Negotiation Framework Document (NFD), dated October 2005, Turkey signed with EU, in related to agricultural policy; three files attract attention as agriculture and rural development, vegetable - animal health, food security, and fishing. The title of "agriculture and rural development", which can be evaluated as the most important one in these files is suspended with the different reasons (Günaydın, 2009).

In 2001, signing Application Project of Agricultural Reform with World Bank in 2001, finance supply toward realization of the commitments given by IMF- Turkey Standby Agreement was realized. TRUP content consists of four components as farmer transition program (alternative product project), restructuring Association of Agricultural Sale Cooperatives, and project and support services (Günaydın, 2009).

The most remarkable one in all agricultural policies applied in Turkey through IMF and WB is the application of Direct Income Support (DIS), in which all agricultural inventions are combined in a single title. DIA was also adopted as an instrument of a production planning considering the increase of productivity and regional differences. Together with Budgetary 2009 DIA application, not allocated allowance, due to insufficient supervision and payments made to landowner not to that making production, turned into an ineffective application. Instead of DIA application, in terms of adaptation to EU regulation, legal arrangements were committed regarding the use of simplified agricultural support system (SPS) (Günaydın, 2009).

DIS payments lead to some economic problems, especially due to problems in land ownership. The application is far from effective because of the different ownership of the land and the producer, inherited problems in agricultural land, and the fact that producers do not direct production despite the support given. Due to these developments in the World Bank Report in 2009, the state focused on different intervention tools; The DIS application was abolished after primarily increasing agricultural input support. Instead, a shift to a premium payment system was made for the area-based product (Ĕgri, 2012).

While the DISs have entered the liquidation process in recent years, the implementation of the Premium Payments has progressed steadily towards becoming the main agricultural support vehicle. Premium payments have been implemented in a rather uneven fashion since the early 1990s for products such as cotton and sunflower, oilseeds such as soya, canola and olive oil, tobacco, tea, cereal, pulses, etc., which are open to production and largely dependent on foreign markets. In the period of 2000-2009, premium supports were applied continuously for cotton, olive oil, oil seeds and tea pruning. Premium applications for tea started in 2003 and for grains in 2005. Until 2005, 80-90\% of the total premium payments went to cotton, olive oil and oil seeds, and the remainder of the remainder. Cereals increased its share of $20 \%$ of bonus payments for three years covering 2005-2007 to 39\% in 2008 and to $49 \%$ in 2009 (Şahinöz, 2010).

Together with innovations and changes in the area of rural development in the world, the most important component of rural development policy of Turkey continuously developed is EU adaptation process. In the framework of EU-Turkey relationships, to the present from 2000s, the IPARD I and IPARD II application of common agricultural policy form the basis of rural development policies of Turkey. Macroeconomic effects of these policies are put in order as development of agricultural and breeding sectors, qualified as the main economic actors of the rural areas, development of agricultural based industry and information based production in terms of production technologies, and strengthening of agricultural mechanization. However, from macroeconomic point of view, the most important effect, forming job opportunities in the rural areas and contributions provided to employment increase (Nazl1, 2015).

IPARD program is expressed as two-staged plan. IPARD II program containing important innovations enlarge the high prioritized sectors in terms of agricultural production as milk, meat, and egg sectors and targets on turning 
sustainable small sized farms into competitive agricultural businesses. Thus, in rural areas creating new job opportunities will be possible. Another of the most important innovations of expanded IPARD II program is not only to increase energy supply, supporting renewable energy sector but also to be able to provide the costs of rural production to reduce (Erarslan, 2015).

In respect with the year 2012, in terms of Turkey depending on meeting $74 \%$ of energy needs via import, renewable energy production in the rural areas becomes more important and urgent policy. Turkey is obliged to find and develop the actions that will provide its own supply security in energy sector. Especially, utilizing biomasses that are the wastes of agriculture, forestry, and breeding sectors, Turkey should develop biomass production. In addition, Turkey should give weight to the policies. At this point, EU support programs have a meaning in terms of the necessary transfer (Özlü, 2015). In diversifying economic activities of rural areas; one of the main elements becomes distinct as rural tourism. In an economy like Turkey, which has an important advantage in terms of tourism, being able to evaluate the existing potential facilitates the realization of rural development (Ün, et al, 2012).

In the framework of DPT (State Planning Organization) $9^{\text {th }}$ Development Plan (2001-2013), it is clearly expressed that the main aim in rural development is that the job and life conditions in the rural area is locally realized in compatible with the urban area and sustainable development. In order to realize the aim defined in the framework of plan, restructuring agricultural sector and solving the macroscopic conditions such as unemployment and poverty are based on and production based supporting policies are foreseen (Kandemir, 2011).

Structural disturbances such as that agriculture in Turkey and agricultural enterprises are small sized, fragmental, and subsistence enterprises; insufficiency in the use of technology, and low productivity lead to the supply demand incompatibility in breeding sector in the domestic markets and low competitive power in foreign markets. Turkey is obliged to realize the effective use of technology, which will enable effectiveness and competitive power to be increased, formation of rural and agricultural infrastructure, and rural development policies toward improving the structure of agricultural businesses. Otherwise, the agricultural businesses in the position not to able to compete and reduction of agricultural production will lead Turkey to fall to a foreign dependent position in the strategic products and even in the products it has competitive advantage (Can and Esengün, 2007). This negative table in the agricultural production will be the most important structural resource of a set of socioeconomic problems such as low growth rate in rural areas, that the prices of agricultural product are high and inflation, unemployment, poverty, and unbalance of income distribution.

It has been observed that developed countries have a positive effect on the agricultural sector while support policies have a negative effect on developing countries. It can be seen that the desired results cannot be achieved for market price and input support for Turkey. This may be due to the structural characteristics of the agricultural sector in Turkey. According to OECD data; In the period of 1995-2010, although Turkey was a leading country in the agricultural support, these supports did not get the desired results unlike the countries such as America, EU, Brazil, China, South Africa, Canada, Russia and Chile (Aktaş, et al, 2013). For Turkey, the problem is support policies that are changed very often in the agricultural sector without going to structural regulation. For example, DIS payments and market price support in force should be associated with agricultural production, should be able to reach real producers, be made in sufficient quantity and on time. In the right context, at the right time and with the right structure, agricultural support policies should be established and maintained in accordance with the realities of the country. For this reason, the policies to be implemented in the agricultural sector must have a long perspective. For this reason, the support policies implemented with the support of the government will be in place in the short term by creating the existing agricultural market structure by joining the account. In the long term, it is necessary to identify the elements that deteriorate the activity especially in agricultural markets and create alternatives (Aktaş, et al, 2013).

It can be argued that agricultural support policies prevent agricultural products from meeting with the market and being involved in the market process rather than correcting the market conditions of the products. If the manufacturer does not act according to market signals, the concern about quality and marketability is totally absent. For example, some problems may arise in the export of poor quality tea or tobacco, damp wheat, which inactivates the market opening target for the supportive products (Doğruel, 1993).

"Agricultural reform", which criticizes traditional agricultural support systems with the argument that "... benefiting very rich farmers from poor farmers ..." and justifies the direct support system; with the new system, the "rich-poor" diversification has further increased. Because in our country where the distribution of the soil is very unstable, a little of $3 \%$ of the landed farmers, about $40 \%$ of the land, and therefore the support of them, cannot benefit from these supports because some $40 \%$ of the farmers in the East and South- It is confiscated by $40 \%$. In short, the new system has further enhanced socio-economic differentiation and social tension in the rural arena (Şahinöz, 2010). 


\section{Conclusion}

Structural instabilities in agricultural product markets affect not only agricultural products but also the production structure of economy in all sectors, determine price movements, and causes important macroeconomic disturbances such as poverty and unbalances of income distribution. On the other hand, irregular urbanization and unemployment, disturbing the demographic structure of population, make the problems more serious. Becoming poor of rural population become the determinative of a general poverty and unfair income distribution, which can affect all society. The beginning point of rural development policy requires the rural area, in which the program will be applied, to be defined and related this definition with population movements. From this point of view, the main aim of all countries of the world is to reduce immigration from the rural areas to the urban areas and form an environment that will make the people' living in the rural areas easy and attractive. Providing this with only direct supports hardly seem to be possible and, therefore, supports given to the projects and investments, allocated with the aim of the rural development, can be more effective than direct supports.

In agriculture there are certain basic and important functions that only the state can install. This role of the state; It also includes the application of protectionist foreign trade policies and import-duplication industrialization strategies in order to realize the structural transformation that has a critical role in important and historical examples of capitalist development. The same is true for land reform, co-operation, and other mechanisms instead of flexible "agricultural institutions". More importantly; requires an intense official credit and incentive program that does not involve excessive interest. Significant interventions of the state are needed in the creation of modern irrigation facilities, the upgrading of new technologies, the control of inter-sectoral prices, and especially rural poverty alleviation programs.

Structural disturbances such as that the agriculture and agricultural enterprises in Turkey are in the feature in small sized, fragmental, and subsistence enterprise; economic unbalances such as inadequacies in technology and use of it, and low productivity lead to the supply -demand incompatibility in breeding sector in the domestic markets and low competitive power in foreign markets.

Turkey is obliged to realize the effective use of technology, which will enable effectiveness and competitive power to be increased, formation of rural and agricultural infrastructure, and rural development policies toward improving the structure of agricultural enterprises. Otherwise, the agricultural businesses in the position not to able to compete and reduction of agricultural production will lead Turkey to fall to a foreign dependent position in the strategic products and even in the products it has competitive advantage. This negative table in the agricultural production will be the most important structural resource of a set of socio economic problems such as low growth rate in rural areas that the prices of agricultural product are high and inflation, unemployment, poverty, and unbalance of income distribution.

\section{References}

- Acar, 2003. "Fiyat Desteğinden Doğrudan Desteğe: Dünyada Tarımsal Destekleme Politikalarında Yeni Yönelimler”, Anadolu Üniversitesi, Sosyal Bilimler Dergisi, 2003/2, pp. 101-116

- $\quad$ Aktaş, et al, 2013. "Farklı Ülkelerdeki Tarımsal Destekleme Politikalarının Tarımsal üretim Üzerine Etkisinin Karşılaştırılmalı Analizi”, Anadolu Üniversitesi Sosyal Bilimler Dergisi, Vol:15 No:4, pp. 55-74

- Byres, 2009. “Tarım ve Kalkınma: Yeni Neo-Klasik Kalkınma İktisadının ve Neo-Klasik Neopopülizmin Eleştirisine Doğru”, Neoliberal Küreselleşme ve Kalkınma, ed: Fikret Şenses, İletişim Yayınları, İstanbul, pp. 387-429

- Can and Esengün, 2007. “Avrupa Birliği Kırsal Kalkınma Programlarının Türkiye’nin Kırsal Kalkınması Açısından İncelenmesi”, GOÜ Ziraat Fakültesi Dergisi, 24 (2), pp. 43-56

- Doğruel, 1993. Tarım Destekleme Politikaları ve Sonuçları ABD, AT ve Türkiye, İstanbul Ticaret Odası Yayın No: 1993-29

- Eğri, 2012. “2000 Sonrası Türk tarım politikalarında Dönüşüm ve Çiftçi Algısı: Kırklareli Örneği”, Anadolu Üniversitesi Sosyal Bilimler Dergisi, Vol:14, No:1, pp. 89-104

- Erarslan,2015. "Kırsal Kalkınmanın Yeni Adresi: TKDK”, Kırsal Kalkınma Dergisi, Say1:2, pp. 43-45

- Eştürk and Ören, 2014. “Türkiye'de Tarım Politikaları ve Gıda Güvencesi”, YYÜ Tarih Bilimleri Dergisi 24 (2), pp. 193-200

- European Commission, 2014. The European Union Explained: Agriculture, p.6

- Giray, et al, 2004. "Kırsal Kalkınmada Yeni Perspektifler”, 6. Türkiye Tarım Ekonomisi Kongresi Conference Paper, p.5

- Günaydın, 2009.“Türkiye Tarım Politikalarında Yapısal Uyum:2000'li Yıllar”, Mülkiyeliler Birliği Dergisi, Cilt: XXXIII, Sayı:262, pp..175-221 
- Kandemir, 2011.“Tarımsal Destekleme Politikalarının Kırsal Kalkınmaya Etkisi”, Ekonomi Bilimleri Dergisi, Cilt:3, No:1, pp. 103-113

- Knickel and Renting, 2000. "Methodological and Conceptual Issues in The Study of Multifunctionality and Rural Development”, Sociologia Ruralis, Vol:40, Number:4, pp. 512-528

- Kulaklıkaya,2015. “Kırsal Kalkınma Çalıştay Açılış Konuşması”, Kırsal Kalkınma Çalıştayı TKDK-D8 Ülkeleri, p.1

- Marsden and Sonnino, 2008. "Rural Development and the Regional State: Denying Multifunctional Agriculture in UK", Journal of Rural Studies, 24, pp. 422-431

- Nazlı,2015. “Kırsal Alanlara Damga Vuran Yatırımlar: IPARD II”, Kırsal Kalkınma Dergisi, Sayı:2, pp. 2833

- Özlü,2015. “Yenilenebilir Enerji Türleri ve Türkiye’nin Yatırım Perspektifi Nasıl Olmalı?”, Kırsal Kalkınma Dergisi, Say1:1, pp. 32-38

- Şahin, 1998. Türkiye Ekonomisi, Ezgi Kitabevi, İstanbul

- Şahinöz, 2010. “Yeni Bin Yıl'da Tarım Politikaları”, Akdeniz Üniversitesi İ.İ.B.F. Dergisi, 19, pp. 331 -349

- Tan, et al, 2010). “Türkiye'de 2000 Yılı Sonrası Uygulanan Tarım Politikaları: Tarım reform Uygulama Projesi -ARIP”, Türkiye IX Tarım Ekonomisi Kongresi, pp. 972-976

- Turhan, 2015. “TKDK Organizasyonel Yapılar ve IPARD Uygulama Süreçleri”, Kırsal Kalkınma Çalıştayı TKDK-D8 Ülkeleri, pp. 17-30

- Ün, 2012.“Ekonomik Kalkınmada Kırsal Turizmin Rolü: Türkiye Örneği”, International Conference on Eurasian Economies, pp. 345-350

- Yalçınkaya, et al, 2006. “Avrupa Birliği’ne Yönelik Düzenlemeler Çerçevesinde Türk Tarım Politikaları ve Sektörün Geleceği Üzerindeki Etkisi”, Yönetim ve Ekonomi, Cilt:13, Sayı:2, pp. 97-118 